\title{
TESTING OF SOME MAIZE HYBRIDS FROM CROATIA IN THE AGROECOLOGICAL CONDITIONS OF KOSOVO
}

\author{
Arsim Elshani ${ }^{1}$, Nexhdet Shala ${ }^{2 *}$, Nazmi Hasanaj ${ }^{3}$, Ibrahim Hoxha ${ }^{4}$ \\ ${ }^{1,2 *, 4}$ University of "Haxhi Zeka", Faculty of Agribusiness, Peja 30000, Kosovo; \\ ${ }^{3}$ Seeds factory "Koal seeds", Istog 30000, Kosovo; \\ *Corresponding Author Nexhdet Shala, e-mail: nexhdet.shala@unhz.eu;
}

Received May 2020; Accepted June 2020; Published July 2020;

DOI: https://doi.org/10.31407/ijees10.311

\begin{abstract}
The study object is the research of the suitability of some maize hybrids (Zea mays L.) from Croatia. There were six cultivars of maize from Croatia: OSSK 403, OS 430, OSSK 515, OSSK 552, OSSK 617, OSSK 635 while as standard check was used hybrid NS 640 which is among the most used hybrids in Kosovo. Most of evaluated maize hybrids showed very high level of adaptability in agro-climatic condition of Kosovo. Six maize hybrids $\mathrm{F}_{1}$ generation from Croatia were tested, during the growing season, in agroclimatic condition of Kosovo. The evaluation was conducted at two different localities of Kosovo known foot different agroclimatic and pedologic characteristics (Peja - Research Station of Kosovo Institute of Agriculture and Pestova - private agriculture company). The agro climatic and pedology conditions of Kosovo, compared to the obtained yields in the maze indicate that one that does not use the full genetic potential of the hybrids that are cultivated in Kosovo. Due to this reason, a new genetic potential was used into this study. The obtained results indicate that the hybrids cultivated in the fields of Pestovo provide a yield that in other attributes like stem and husk is better than maze cultivated in the fields of Peja. in which trials has been investigated the yield, crude, protein, content and other relevant traits of.
\end{abstract}

Key words: crude protein content, grain yield, phenological traits of maize hybrids. 